\title{
Pengembangan Model Aplikasi Simulator Kamera Video Berbasis Android Untuk Mata Kuliah Sinematografi Pembelajaran
}

\author{
Heri Triluqman ${ }^{4}$, Mulyoto5 ${ }^{5}$ Leo Agung Sutimin 6 \\ heritl@student.uns.ac.id
}

\begin{abstract}
Abstrack: Integrating information and communication technology (ICT) in the learning process continues to evolve with various patterns and strategies, grouped into (1) e-Learning system, the process of learning that utilizes electronic devices and digital media, and (2) $m$ - Learning, or mobile learning, the process of learning that utilizes mobile communication technology and devices. The rapid development of mobile devices, relatively easy operations, and more affordable prices, is a supporting factor in the widespread use of mobile learning to become a new alternative of learning media. These conditions encourage the formation of learning paradigm that can be done anytime and anywhere. The aim of the research is to develop the design/model of an Android-based Camcorder Simulator Application for the students of cinematography courses majoring education technology of education faculty in Semarang State University. This research method refers to the research and development (R\&D) proposed by Borg and Gall (in Sukmadinata, 2016) with some modifications that have been developed by Sukmadinata. Withal, the research procedures used in this study focus on the development stages of application model/design. This step includes the following steps; (1) Model development (product design), (2) Design validation, and (3) Design revisions. The results of this study indicate that the process of developing an android-based camcorder simulator application model is done through the steps according to the research procedures, beginning with requirement analysis, then compiling competency map, material map, the main point of media content (GBIM), material descriptions (JM), flowchart and script, then design validation and product revision. Modeling camcoder simulator application is also ready for further stage of research and development. The use of an android-based camcorder simulator application is demanded in the learning process of cinematography course, especially the engineering material and the shooting procedure as it can assist students to be autonomous learners.
\end{abstract}

Keyword: Model Development, Camcoder Simulator, Android

\footnotetext{
${ }^{4}$ Mahasiswa Magister Teknologi Pendidikan Universitas Sebelas Maret Surakarta

5 Dosen Universitas Sebelas Maret Surakarta

${ }^{6}$ Dosen Universitas Sebelas Maret Surakarta
} 


\section{PENDAHULUAN}

P emanfaatan teknologi informasi dan komunikasi (TIK) dalam dunia pendidikan terus berkembang dalam berbagai pola dan strategi. Pada umumya dapat diklasifikasikan dalam 2 (dua) kelompok, yaitu: (1) Sistem e-Learning sebagai bentuk pembelajaran yang memanfaatkan perangkat elektronik dan media digital, dan (2) mobile learning (m-learning) sebagai bentuk pembelajaran yang khusus memanfaatkan perangkat dan teknologi komunikasi bergerak. Saat ini penggunaan atau penerapan mobile learning sebagai sebuah kecenderungan baru dalam belajar, membentuk paradigma pembelajaran yang dapat dilakukan kapanpun dan dimanapun semakin meluas. Beberapa faktor pendorong hal tersebut, di antaranya adalah tingkat perkembangan perangkat bergerak yang sangat tinggi, tingkat penggunaan yang relatif mudah, dan harga perangkat yang semakin terjangkau, dibandingkan dengan perangkat komputer personal (Rusman, 2013).

Pengintergrasian TIK dalam pembelajaran di perguruan tinggi tentunya juga membutuhkan sarana dan prasarana yang memadai, terutama untuk perkuliahan praktik yang secara langsung membutuhkan peralatan dalam proses pembelajarannya. Peralatan dalam jumlah yang memadai baik dari sisi kualitas dan kuantitas tentunya akan berpengaruh terhadap hasil belajar mahasiswa dan menentukan kompetensi yang akan di capai. Kondisi yang kurang ideal di alami mahasiswa prodi Teknologi Pendidikan FIP Unnes, khususnya untuk peserta mata kuliah Sinematografi Pembelajaran. Jumlah peralatan (kamera video) yang sangat terbatas di banding jumlah mahasiswa, membuat mahasiswa membutuhkan waktu lebih lama dalam belajar mengenal dan mengoperasikan kamera video.

Kamera video yang dimiliki laboratorium prodi Teknologi Pendidikan sejumlah 6 unit (4 unit merk Panasonic dan 2 unit merk Sony) di bandingkan dengan 76 mahasiswa peserta mata kuliah senematografi pembelajaran dalam 1 semester. Dengan kondisi seperti itu, untuk mengakselerasi proses belajar mahasiswa, maka perlu dikembangkan suatu media yang memungkinkan mahasiswa dapat belajar terlebih dahulu sebelum memegang peralatan kamera video secara langsung. Oleh karenanya, penelitian ini memiliki tujuan untuk mengembangkan desain model aplikasi simulator kamera video berbasis android untuk mata kuliah sinematografi pembelajaran prodi Teknologi Pendidikan FIP Unnes.

Istilah mobile learning mengacu kepada penggunaan perangkat teknologi informasi genggam dan bergerak, seperti handphone, dalam pembelajaran. Kemampuan penting yang harus dimiliki oleh perangkat pembelajaran mobile learning diantaranya adalah adanya kemampuan untuk terkoneksi ke peralatan lain (terutama komputer), kemampuan menyajikan informasi pembelajaran dan kemampuan untuk mewujudkan komunikasi antara pengajar dan pembelajar. Mobile learning ialah pembelajaran yang unik sebab pembelajar bisa mengakses materi pembelajaran, arahan dan aplikasi yang berkaitan dengan pembelajaran, kapanpun dan dimanapun. Hal tersebut dapat meningkatkan konsentrasi pada materi pembelajaran, serta dapat mendorong motivasi pembelajar untuk melakukan pembelajaran seumur hidup (life long learning).

Berdasar data dari website wearesocial.sg yang dikutip pada bulan Januari 2014, jumlah pengguna mobile devices di Indonesia mencapai 281.963.665. Hal tersebut menunjukkan angka sebesar $112 \%$ dari jumlah penduduk Indonesia yang mencapai sekitar 250 juta jiwa (Horwitz, 2014). Sumber yang sama juga menyebutkan bahwa untuk jenis sistem operasi, pengguna smartphone di Indonesia sebagian besar menggunakan Android.

Android merupakan platform sistem operasi pada perangkat mobile (seperti smartphone/telepon selular atau sejenisnya) yang sudah banyak digunakan oleh berbagai vendor. Jika belum bisa mengembangkan aplikasi atau memang tidak berminat menjadi pengembang dikarenakan keterbatasan kemampuan, kita bisa memanfaatkannnya sebagai pengguna. Berbagai aplikasi dalam smartphone dapat dimanfaatkan sebagai sumber belajar untuk siswa, mahasiswa atau guru (Urip, 2011). Android yang dikembangkan oleh Google merupakan sistem operasi yang bersifat open source. Hal tersebut memungkinkan pihak lain berkontribusi untuk memberikan sumbangsih dalam pengembangannya. Sama 
halnya seperti Linux (sistem operasi untuk komputer), Android juga mengalami perkembangan yang sangat pesat.

Perubahan dan inovasi bidang TIK dalam dunia pendidikan tersebut di atas terus berkembang. Beberapa perubahan yang terjadi di antaranya adalah (a) lebih mudah dalam mengakses dan mengembangkan sumber belajar, (b) lebih bervariasinya pilihan menggunakan dan memanfaatkan Teknologi Informasi dan Komunikasi (TIK) dalam pembelajaran, (c) semakin meningkatnya kontribusi media dan multimedia dalam proses pembelajaran, (d) waktu belajar menjadi lebih fleksibel, (e) implementasi pembelajaran berbasis komputer, (f) pemanfaatan media video/televisi, e-learning, mobile learning, dan e-library, serta (g) kurikulum online. Perubahan dan inovasi tersebut memiliki implikasi yang sangat luas bagi dunia pendidikan, yaitu perubahan dalam program pembaharuan terapan teknologi pembelajaran, perubahan metode dan model pembelajaran, serta mengintegrasikan TIK dalam proses pembelajaran (Rusman, 2013).

Perubahan-perubahan itulah yang menuntut dunia pendidikan melakukan inovasi dan mengembangkan kreativitas dalam kegiatan pembelajaran. Banyak pihak yang membicarakan pembaruan dalam proses pembelajaran, akan tetapi sedikit yang membahas mengenai solusi pemecahan masalah tentang proses pembelajaran kontemporer. Penyesuaian keilmuan terhadap perkembangan bidang TIK yang sangat pesat dengan harapan untuk mencetak sumber daya manusia yang berkualitas merupakan kebutuhan yang tidak dapat dihindari. Pendidik diharapkan mampu mengintegrasikan TIK dalam pembelajaran supaya kualitas proses dan hasil pembelajaran menjadi lebih baik, sehingga peningkatan kualitas pendidikan Indonesia dapat di capai. Kondisi tersebut tentunya juga diharapkan terjadi pada proses pembalajaran di perguruan tinggi, khususnya pada program studiprogram studi di LPTK yang merupakan kawah candradimuka nya para calon guru.

Penelitian yang sudah pernah dilakukan dan relevan dengan penelitian ini diantaranya adalah penelitian yang dilakukan Permadi (2013) yaitu penelitian pengembangan aplikasi game simulasi virtual tingklik dan suling bali berbasis android. Prameswari (2009) melakukan penelitian tentang "pengembangan aplikasi simulasi mesin mobil berbasis multimedia". Kemudian penelitian oleh Soemapraja (2014) tentang pengembangan aplikasi simulasi perdagangan saham dengan sector rotation dan linear programming. Peneltian lainnya dilaksanakan oleh Pasarai (2010) tentang pengembangan dan aplikasi simulator reservoir untuk simulasi perkolasi gas pada reservoir bertenaga dorong gas terlarut.

Penelitian-penelitian tersebut memiliki kemiripan, yaitu sama-sama mengembangkan sebuah aplikasi sebagai media simulasi. Akan tetapi dari berbagai penelitian yang ada, saya belum menemukan penelitian mengenai aplikasi simulasi untuk media belajar dengan materi kamera video. hal tersebut yang juga menjadi salah satu pertimbangan tim peneliti mengusulkan topik penelitian ini. Penelitian lainnya yang terkait dengan pengembangan atau penggunaan aplikasi android sebagai media pembelajaran sudah banyak dilaksanakan dalam beberapa tahun terakhir.

Beberapa penelitian tersebut dapat di uraikan sebagai berikut: (a) Purbasari (2013) melaksanakan penelitian mengenai pengembangan aplikasi android sebagai media pembelajaran matematika pada materi dimensi tiga untuk siswa SMK kelas X. (b) Penelitian Sambodo (2014) mengenai pengembangan media pembelajaran mobile learning ( $m$-learning) berbasis android pada materi sistem peredaran darah manusia untuk siswa kelas XI SMA/MA. (c) Kusuma (2013) melakukan penelitian tentang perancangan aplikasi mobile edukatif 'belajar chord piano untuk pemula' berbasis android. (d) Penelitian lainnya, dilakukan oleh Sutanto (2013) dengan judul perancangan aplikasi edukasi "smart brain kids" berbasis android sebagai media pembelajaran untuk anak usia dini.

Penelitian-penelitian tersebut menekankan pada pemanfaatan aplikasi berbasis android sebagai media pembelajaran. Aplikasi yang dikembangkan merupakan media yang dapat digunakan oleh user untuk belajar tentang sesuatu materi tertentu. selama ini penelitian yang berkaitan dengan pemanfaatan 
aplikasi android, lebih banyak menjadikan anak usia paud hingga pelajar SMA/sederajat sebagai subjek penelitiannya.

\section{METODE PENELITIAN}

Metode penelitian ini mengacu pada strategi penelitian dan pengembangan yang dikemukakan oleh Borg dan Gall (dalam Sukmadinata, 2016) dengan beberapa modifikasi yang telah dikembangkan oleh Sukmadinata. Adapun dalam artikel ini, prosedur penelitian yang digunakan dalam penelitian fokus pada tahap kedua, yaitu tahap pengembangan model. Dalam tahap ini, penelitian yang dilakukan mencakup langkahlangkah sebagai berikut (1) Model pengembangan (desain produk), (2) Validasi desain, (3) Revisi desain.

Penelitian dilaksanakan di laboratorium program studi Teknologi Pendidikan FIP Unnes, pada bulan Mei-Juli 2017, dengan subject penelitian adalah mahasiswa semester 2 tahun pelajaran 2016-2017 yang menempuh mata kuliah sinematografi pembelajaran.

\section{HASIL PENELITIAN DAN PEMBAHASAN}

Subjek penelitian ini adalah mahasiswa prodi Teknologi Pendidikan FIP Unnes semester 2 (dua) yang menempuh mata kuliah sinematografi pembelajaran. Jumlah responden sebanyak 77 mahasiswa dari 2 (dua) rombel. Berdasar hasil kuesioner yang diisi oleh mahasiswa, diperoleh data-data sebagaimana diuraikan pada penjelasan berikut. Jumlah smartphone yang dimiliki mahasiswa adalah sebagai berikut: 94,8\% mahasiswa hanya memiliki 1 (satu) smartphone, sementara 5,2\% mahasiswa memiliki 2 (dua) buah smartphone. Data ini juga menunjukkan bahwa tidak ada satupun mahasiswa yang memiliki lebih dari 2 (dua) smartphone.

Berdasarkan hasil "Studi Kebutuhan Pengembangkan Aplikasi Simulator Kamera Video Berbasis Android di Program Studi Teknologi Pendidikan FIP Unnes" yang telah dipublikasikan sebelumnya (Triluqman, 2017), dapat di tarik simpulan dalam 2 (dua) aspek, yaitu aspek analisis kebutuhan aplikasi dan aspek kemampuan awal mahasiswa.

Pada aspek kebutuhan aplikasi yang akan dikembangkan, setidaknya dapat di operasikan pada smartphone dengan spesifikasi minimal seperti : (1) Menggunakan sistem operasi Android, versi 4.0 (Ice Cream Sandwich) atau setelahnya, (2) aplikasi simulator kamera video yang akan dikembangkan dapat beroperasi optimal pada smartphone dengan RAM kurang dari $1 \mathrm{~GB}$, dan ROM kurang dari $8 \mathrm{~GB}$.

Tabel 1. Versi Android pada Smartphone Mahasiswa

\begin{tabular}{lll}
\hline No & \multicolumn{1}{c}{ Versi Android Yang Digunakan } & \% Jumlah Pemilik \\
\hline $\mathbf{1}$ & Android v7.0 Nougat & $3,9 \%$ \\
\hline $\mathbf{2}$ & Android v6.0 Marshmallow & $15,6 \%$ \\
\hline $\mathbf{3}$ & Android v5.0 - 5.1 Lollipop & $39 \%$ \\
\hline $\mathbf{4}$ & Android v4.4 Kitkat & $24,7 \%$ \\
\hline $\mathbf{5}$ & Android v4.1 - 4.3 Jelly Bean & 14,3 \\
\hline $\mathbf{6}$ & Android v4.0 Ice Cream Sandwich & $0 \%$ \\
\hline $\mathbf{7}$ & Android v3.0 - 3.2 Honeycomb & $1,3 \%$ \\
\hline $\mathbf{8}$ & Android v2.3 Gingerbread (dan/atau versi & $3,9 \%$ \\
& sebelumnya) & \\
\hline
\end{tabular}


Adapun terkait aspek kemampuan awal mahasiswa, berimplikasi pada pokok-pokok materi yang akan disematkan ke dalam aplikasi, secara urutan skala prioritas di sebutkan sebagai berikut: (1) Dubbing gambar dari kamera video / kamera video ke perangkat video lainnya, (2) menu "Intelligent auto mode", (3) menu pengaturan, (4) fungsi image stabilizer, (5) setting recording / play back, (6) jenis-jenis memory card, (7) penggunaan layar menu, (8) Menghubungkan kamera video/kamera video ke Komputer/Laptop, (9) melakukan perekaman manual. (10) merekam dengan focus manual, (11) Cara menonton rekaman/gambar pada kamera video/kamera video melalui Televisi, (12) memasang dan melepas battery kamera video/kamera video, (13) prosedur charging yang baik, (14) memasang / melepas memory card, (15) menggunakan/memegang kamera video/kamera video untuk merekam, (16) menghapus rekaman video/foto (17) menggunakan fungsi zoom in/out, (18) Cara menyalakan/mematikan kamera video/kamera video.

Secara garis besar, kemampuan awal mahasiswa peserta mata kuliah sinematografi pembelajaran dapat dilihat pada gambar berikut:

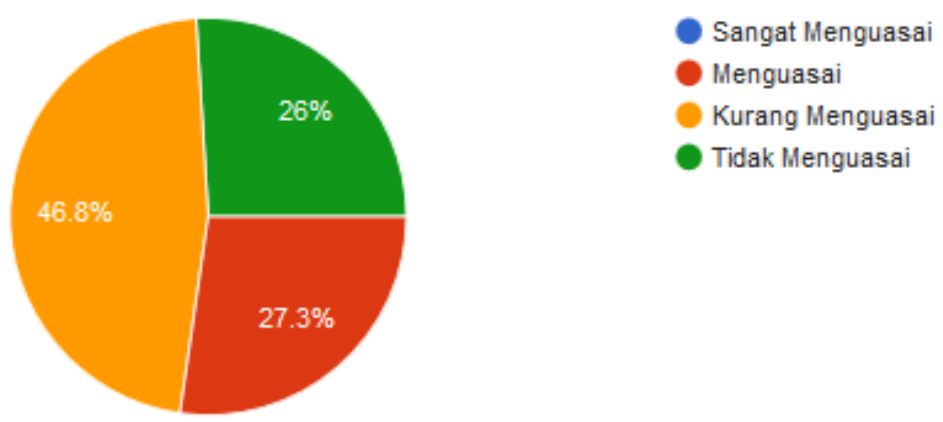

Gambar 1. Kemampuan Awal Mahasiswa dalam Menggunakan Menu Pengaturan pada Kamera Video

\section{Peta Kompetensi}

Peta Kompetensi adalah tujuan yang akan dicapai dalam pembelajaran. Kompetensi yang ingin di capai melalui aplikasi simulator kamera video ini adalah mahasiswa menguasai teknik-teknik pengambilan gambar. Peta kompetensi dalam pengembangan aplikasi sebagai berikut:

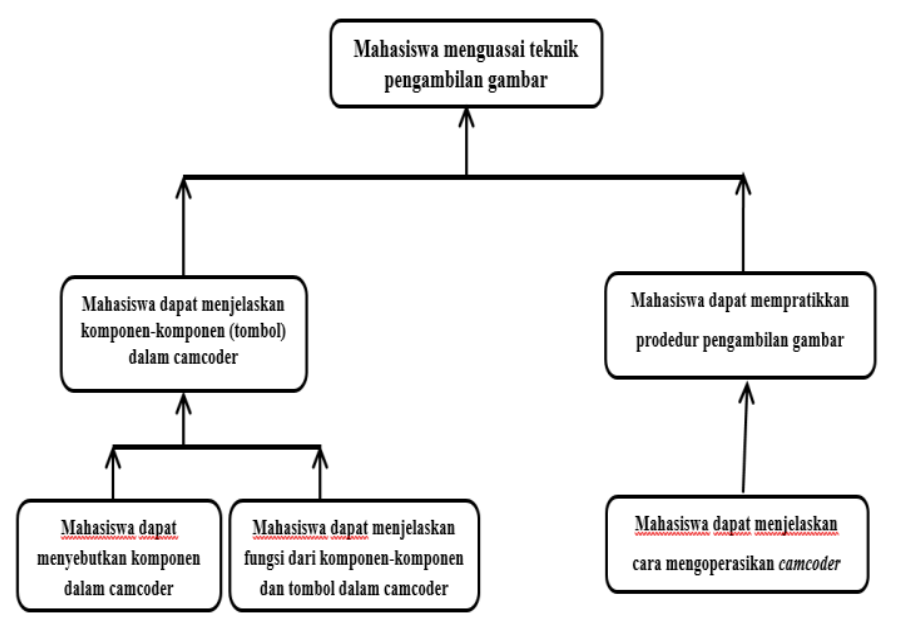

Gambar 2. Peta Kompetensi Aplikasi Simulator Kamera Video 


\section{Peta Materi}

Peta materi adalah gambaran tentang materi apa saja yang akan dipelajari dari naskah dan program yang nantinya akan dibuat. Materi yang akan dibahas dalam aplikasi ini adalah teknik-teknik pengambilan gambar dengan kamera video, beserta materi turunannya, yang dapat dilihat secara lebih detail dalam gambar berikut:

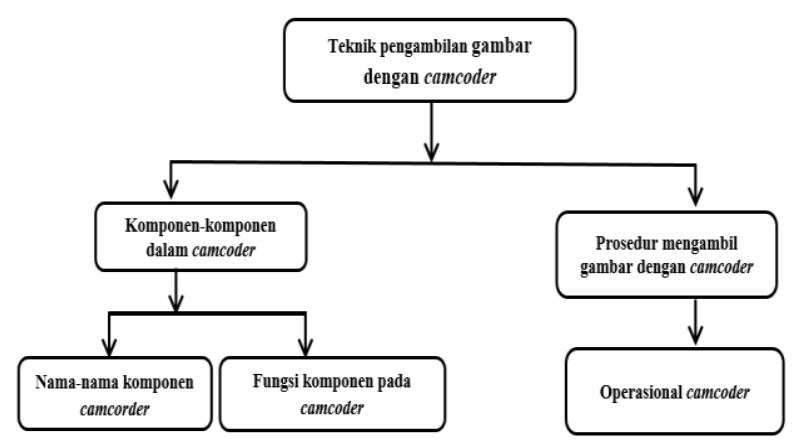

Gambar 3. Peta Materi Aplikasi Simulator Kamera Video

\section{GBIM}

GBIM merupakan singkatan dari Garis Besar Isi Media yang berisi rangkuman menu, tujuan/indikator, materi, bentuk evaluasi dan media apa saja yang akan digunakan dalam naskah nantinya. GBIM untuk aplikasi simulator kamera video ini di susun sebagai penjabaran peta kompetensi dan peta materi yang ada. Konten dalam GBIM juga berdasarkan RPS (Rencana Pembelajaran Semester) mata kuliah sinematografi pembelajaran.

Secara garis besar, GBIM aplikasi simulator kamera video memuat hal-hal sebagi berikut: (a) Menu : berisi pokok-pokok materi sesuai dengan peta materi, yaitu komponen kamera video dan prosedur pengambilan gambar dengan kamera video. (b) Tujuan/Indikator: berisi kompetensi/indikator yang ingin dicapai sesuai dengan peta kompetensi, yaitu mahasiswa dapat menjelaskan komponen-komponen (tombol) dalam kamera video, serta mahasiswa dapat mempratikkan prodedur pengambilan gambar. (c) Materi: berisi penjelasan materi apa saja yang akan dibahas pada menu tersebut. Pada menu komponen kamera video, akan membahas materi tentang nama-nama komponen/menu pada kamera video beserta fungsi-fungsinya. Sementara prosedur pengambilan gambar dengan kamera video, fokus pada materi operasional kamera video. (d) Media : mendeskripsikan mengenai media apa yang akan ada di setiap materi tersebut. Pada aplikasi simulator kamera video, media yang digunakan lebih banyak berupa teks, grafis, dan video. (e) Keterangan: berisi tentang sumber / buku rujukan bila diperlukan dalam pengembangan aplikasi. Rujukan disini banyak menggunakan manual book dari salah satu jenis kamera video yang dimiliki oleh laboratorium jurusan Kurikulum dan Teknologi Pendidikan FIP Unnes.

Guna memperjelas GBIM, juga di susun jabaran materi yang merupakan penjelasan dari kolom materi pada GBIM. Pada Jabaran Materi dipaparkan pokok-pokok materi yang dibahas pada masingmasing menu. Jabaran materi disini sebagai pedoman saja, tidak terlalu detail, karena detailnya di uraian pada naskah media.

\section{Naskah Media/Aplikasi}

Untuk merancang sebuah media pembelajaran yang baik dan terstruktur sebaiknya disusun sebuah panduan atau storyboard ata naskah untuk merancang media, termasuk dalam membuat suatu aplikasi sebagai media pembelajaran. Naskah inilah yang digunakan sebagai panduan untuk pembuatan program aplikasi simulator kamera video. 
Penulisan sebuah naskah media dimulai dari penulisan peta kompetensi, peta materi dan GBIM. Dokumen tersebut diatas berguna sebagai panduan dan kerangka awal untuk membuat sebuah naskah. Dengan adanya dokumen-dokumen tersebut naskah yang dihasilkan akan lebih terstruktur.

Dalam menulis naskah media/aplikasi simulator kamera video, secara garis besar terdiri dari 3 bagian, yaitu : (a) Kepala naskah, (b) Tampilan, (c) Keterangan. Contoh tampilan naskah media/aplikasi dapat di tampilkan berikut ini:

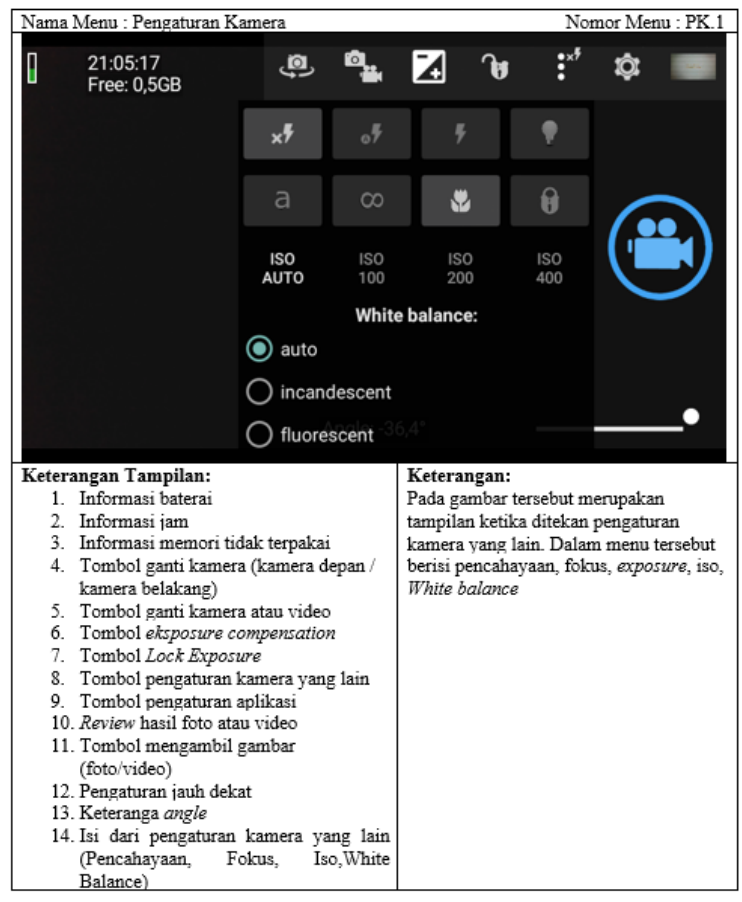

Gambar 4. Contoh Naskah Aplikasi Simulator Kamera Video

\section{Produksi Aplikasi Simulator Kamera video}

Dalam pengembangan aplikasi simulator kamera video, peneliti mengembangkannya sesuai dengan bahan acuan yang telah disusun sebelumnya. Bahan acuan tersebut diawali dengan analisi kebutuhan, kemudian menyusun peta kompetensi, peta materi, Garis Besar Isi Media (GBIM), Jabaran Materi, Flowchart dan Naskah. Semua bahan acuan itu digunakan sebagai pengendali proses pengembangan agar tidak melenceng dari konsep pengembangan awal. Sehingga aplikasi yang di kembangkan tetap terarah untuk mencapai tujuan dan kompetensi yang ditetapkan.

Berdasarkan desain yang telah di susun, langkah berikutnya adalah memproduksi aplikasi simulator kamera video menggunakan software terkait, dalam hal ini software utama yang digunakan adalah android studio. Software lain yang digunakan adalah software pengolah gambar. Contoh desain tampilan aplikasi simulator kamera video yang dikembangkan, dapat dilihat pada gambar berikut. 


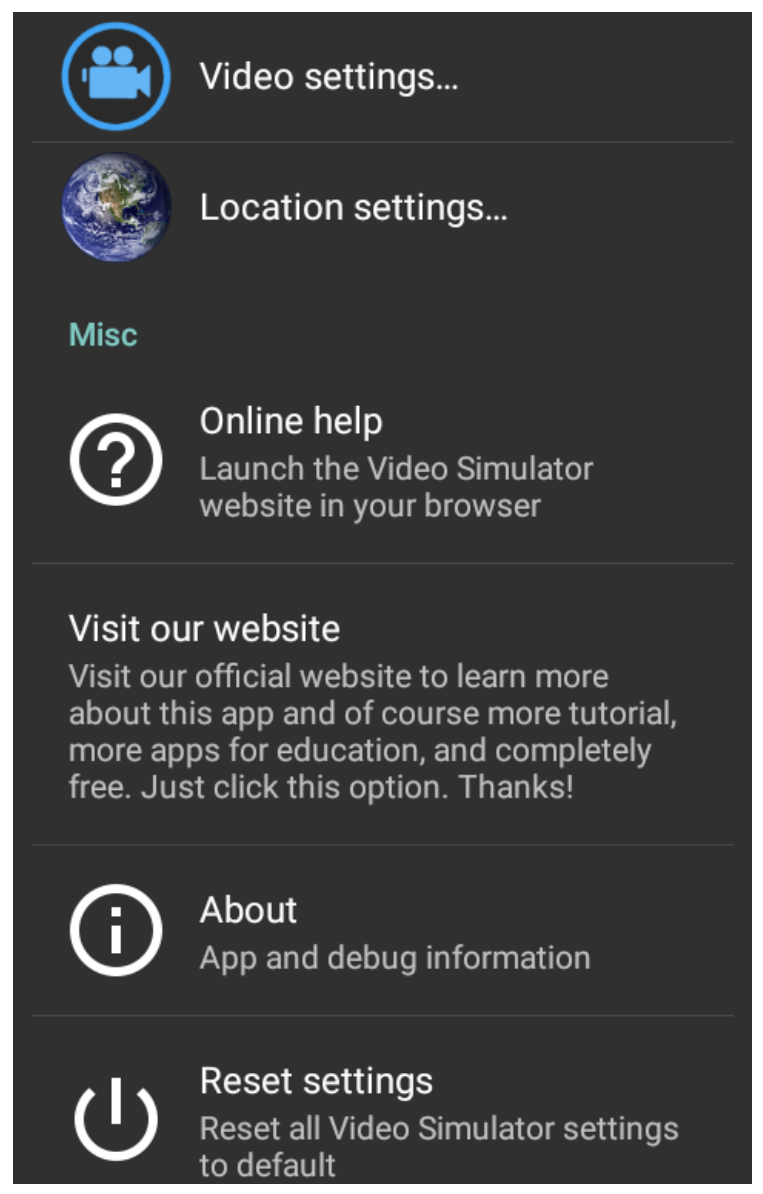

Gambar 5. Contoh Desain Tampilan Aplikasi Simulator Kamera Video

Untuk mengetahui ketahanan dan performa aplikasi simulator kamera video berbasis android, maka dilakukan evaluasi. Evaluasi ini dilakukan melalui beberapa tahap, dimulai oleh peneliti sendiri kemudian di lanjutkan oleh ahli media dan ahli materi. Validasi yang dilakukan oleh peneliti dilakukan untuk mengetahui keberhasilan fungsi tombol-tombol navigasi, apakah tombol tersebut sudah berfungsi dengan baik dan sesuai dengan materi yang dituju.

\section{Validasi Desain}

Untuk mengetahui kehandalan dan performa aplikasi simulator kamera video berbasis android, maka dilakukan validasi. Validasi ini dilakukan melalui beberapa tahap, dimulai oleh peneliti sendiri kemudian di lanjutkan oleh ahli media dan ahli materi. Validasi yang dilakukan oleh peneliti dilakukan untuk mengetahui bahwa aplikasi ini berjalan secara fungsional. Hal ini dilakukan untuk memastikan setiap komponen dalam aplikasi ini dapat berfungsi sesuai dengan yang direncanakan.

Tahap validasi media selanjutnya adalah mengujikannya kepada ahli media dan ahli materi. Aspek yang diujikan oleh ahli media adalah, tentang aspek rekayasa peraangkat lunak dan aspek desain komunikasi visual. Adapun untuk ahli materi, validasi pada aspek desain pembelajaran. Hasil validasi ahli media menunjukkan skor 88 dengan kategori sangat baik, sementara untuk ahli materi mendapat skor 85 dengan kategori sangat baik juga.

\section{Revisi Desain}

Berdasarkan hasil validasi media dan validasi materi, peneliti melakukan evaluasi terhadap aplikasi simulator kamera video berbasis android tersebut. Setelah dievaluasi, selanjutnya dilakukan proses 
revisi pada beberapa bagian yang menjadi catatan para validator. Sehingga aplikasi yang dikembangkan akan menjadi sebuah produk yang lebih baik lagi dan dapat dimanfaatkan dalam proses pembelajaran mata kuliah sinematografi.

\section{KESIMPULAN}

Dalam pengembangan model aplikasi simulator kamera video berbasis android untuk mata kuliah sinematorgrafi pembelajaran, peneliti mengembangkannya sesuai dengan bahan acuan yang telah disusun sebelumnya. Bahan acuan tersebut diawali dengan analisis kebutuhan, kemudian menyusun peta kompetensi, peta materi, Garis Besar Isi Media (GBIM), Jabaran Materi, Flowchart dan Naskah. Semua bahan acuan itu digunakan sebagai pengendali proses pengembangan agar tidak melenceng dari konsep pengembangan awal. Sehingga aplikasi yang di kembangkan tetap terarah untuk mencapai tujuan dan kompetensi yang ditetapkan. Proses selanjutnya adalah melakukan validasi media dan validasi materi kepada pakar di bidangya, kemudian merevisi aplikasi tersebut berdasarkan catatan dari validator, sehingga aplikasi siap digunakan.

\section{SARAN}

Saran yang dapat dikemukakan dalam penelitian ini adalah aplikasi berbasis mobile sebaiknya dapat dikembangkan untuk media pada mata kuliah lain, yang tentunya disesuaikan dengan kompetensi yang ingin dicapai dan karakteristik materi ajar.

\section{DAFTAR PUSTAKA}

Horwitz, J. (2014). Statistik pengguna internet di Asia dan Indonesia. http://id.techinasia.com. Diunduh 15 November 2015

Kusuma, A. C. (2013). Perancangan Aplikasi Mobile Edukatif 'Belajar Chord Piano Untuk Pemula' Berbasis Android. STIMIK AMIKOM Yogyakarta

Pasarai, U. (2010). Pengembangan dan Aplikasi Simulator Reservoir Untuk Simulasi Perkolasi Gas pada Reservoir Bertenaga Dorong Gas Terlarut. Lembaran publikasi Minyak dan Bumi, 44(3)

Permadi, I. N. A. (2013). Pengembangan Aplikasi Game Simulasi Virtual Tingklik Dan Suling Bali Berbasis Android. Jurnal KARMAPATI, 2(6).

Prameswari, L. P. D. (2009). Pengembangan Aplikasi Simulasi Mesin Mobil Berbasis Multimedia. UATY Yogyakarta.

Purbasari, R. J. (2013). Pengembangan Aplikasi Android sebagai Media Pembelajaran Matematika pada Materi Dimensi Tiga untuk Siswa SMK Kelas X. UM Malang (jurnal-online.um.ac.id).

Rusman, dkk. (2013). Pembelajaran Berbasis Teknologi Informasi dan Komunikasi. Jakarta: Rajawali Pers.

Sambodo, R. A. (2014). Pengembangan Media Pembelajaran Mobile Learning (M-Learning) Berbasis Android pada Materi Sistem Peredaran Darah Manusia untuk Siswa Kelas XI SMA/MA. UIN Sunan Kalijaga Yogyakarta (Skripsi).

Soemapradja, T. G. (2014). Pengembangan Aplikasi Simulasi Perdagangan Saham Dengan Sector Rotation Dan Linear Programming. Binus Business Review, 5 (1), 418-428. 
Sutanto, A. D. (2013). Perancangan Aplikasi Edukasi "Smart Brain Kids" Berbasis Android sebagai Media Pembelajaran untuk Anak Usia Dini. STIMIK AMIKOM Yogyakarta.

Urip. 2011. Android, Sarana dan Sumber Alternatif Belajar Kimia. Diunduh dari www.urip.wordpress.com. 